\section{O Cariri do forró eletrônico: festa, gênero e criação no Nordeste contemporâneo}

\author{
Roberto Marques \\ r-marques01@uol.com.br \\ Tese de Doutorado \\ Programa de Pós-Graduação em Sociologia e Antropologia \\ Universidade Federal do Rio de Janeiro \\ Rio de Janeiro (RJ) 2011
}

\section{The electronic forró in Cariri: dance parties, gender, and creation in contemporary Brazilian Northeast}

\author{
Roberto Marques \\ r-marques01@uol.com.br \\ Doctoral Thesis \\ Post-Graduate Program in Sociology and Anthropology \\ Federal University of Rio de Janeiro \\ Rio de Janeiro (RJ) - Brazil 2011
}

O presente trabalho utiliza material etnográfico das festas de forró eletrônico no Cariri, a fim de explicitar diferentes maneiras de apropriação do típico como forma de representação e apresentação de si aos outros. Em dissonância à referência do forró como dança de pares em uma paisagem marcada pela tradição e pessoalidade, tenta-se mostrar que sua prática contemporânea como espetáculo possibilita a incorporação criativa de diferentes projetos pelos sujeitos ali presentes, tecidos a partir de citações comumente associadas ao mundo urbano. Tal abordagem matiza as críticas sofridas pela reinvenção do ritmo, ocorrida após a década de 1990, por sua íntima relação com a indústria cultural, pela recepção e citação contínua de formas e produtos distribuídos pelo universo pop, pela banalização do corpo feminino e das relações familiares estáveis. Em vez de denunciar uma pretensa falta de capacidade de dotar o universo local de sentido, busca-se compreender o forró eletrônico a partir das narrativas de seus participantes, em uma triangulação: palco - indivíduo na plateia - antropólogo. Por meio das formas de estar na festa - performances, narrativas, sequências de atitudes e falas -, analisam-se os lugares criados pelos indivíduos em suas interações com outros indivíduos. Além disso, para que se possa afastar a ideia de ação como ato definidor de identidades fixas para os participantes das festas, utilizam-se as narrativas dos participantes sobre experiências de deriva, e diversificação da espacialização em um ambiente rural pretensamente controlado e encenação do anonimato. Tenta-se aqui, portanto, falar não apenas sobre o forró como espetáculo, mas também de um Cariri usualmente deixado de lado pela inflação de alguns de seus signos identitários mais frequentemente visitados. $\bigcirc$ forró eletrônico permite, assim, perceber uma forma de pensamento ali presente: um Cariri do forró eletrônico, em suas formas criativas e na gestão de identidades e anonimatos instaurados pela sonoridade do ritmo.
The present work employs ethnographic material from the dance events of electronic forró in the Cariri region to understand how individuals use the typical as representation and presentation to others. Instead of considering forró as a dance of couples in a place characterized by tradition and personhood, the research shows this present-day practice as a spectacle that permits the creative incorporation of different personal projects by the players, constructed from citations commonly associated with the urban world. This approach blurs the criticism on the reinvention of the rhythm that occurred after the 1990s, justified by the close relation of electronic forró with cultural industry; by the constant reception and citation of forms and products distributed by the pop world; and by the trivialization of female bodies and stable family relationships. Instead of criticizing the current rhythm for its lack of capacity to provide the local universe with meaning, we seek to understand the electronic forró through the narratives of the participants in a triangular scheme: stage - audience - anthropologist. We analyze the ways of being in the party - performances, narratives, sequences of actions and speeches - and also the places created by individuals in their interactions with other individuals. Digressing experiences, spatial diversification in a supposedly controlled rural environment, and the anonymous staging were connected in this work in order to eschew the idea of performance as a defining act of the players' identity. We highlight the forró in the region of Cariri not only as a spectacle but also as a place overlooked due to the inflation of some identity signs that are most frequently visited. This dance party allows us to see a thought pattern that is part of it: the electronic forró in Cariri region, including its creative shapes, and the identity and anonymity management established by the rhythm of the music. 